\title{
Materiaey
}

KLIO. Czasopismo poświęcone dziejom Polski i powszechnym

PL ISSN 1643-8191, t. 22 (3)/2012, s. 155-166

Teresa Astramowicz-Leyk

(Olsztyn)

\section{Projekt ustroju Państwa Polskiego z 9 listopada 1942 roku}

W

połowie października 1941 roku w Londynie pojawił się Stanisław Grabski. Był gorącym zwolennikiem premiera generała Władysława Sikorskiego. Od razu dał się poznać nie tylko jako zwolennik premiera, ale i inicjator opracowania zarysu przyszłego ustroju państwa polskiego. 27 października Rada Ministrów przyjęła wniosek premiera o powołaniu Komisji Spraw Ustrojowych (KSU) przy Prezesie Rady Ministrów. Jej zadaniem miało być przygotowanie projektu przyszłego ustroju politycznego i gospodarczego Polski ${ }^{1}$. W skład powołanej Komisji weszli zwolennicy premiera ${ }^{2}$. Pracami kierował Grabski.

Komisja przygotowała dokument zawierający 9 rozdziałów i 74 tezy. Otrzymał on nazwę Zasady przysztego ustroju państwowego Polski i został przyjęty przez Komisję jednogłośnie 21 stycznia 1942 roku. Praca KSU przypadła na okres, kiedy nie funkcjonowała Rada Narodowa RP. Jak podkreśla Eugeniusz Duraczyński, premier Sikorski nie przedstawił tego dokumentu Radzie Ministrów. W marcu 1942 roku Zasady... trafily pod obrady dopiero co powołanej II Rady Narodowej. Zabierając głos w imieniu rządu, wicepremier Stanisław Mikołajczyk poinformował, że rząd nie traktuje tego dokumentu, jako

${ }^{1}$ E. Duraczyński, Projekt ustroju państwowego Rzeczypospolitej (21 stycznia 1942), [w:] idem, Sprawy polskie minionego wieku. Szkice, Kraków 2011, s. 145-152.

2 Pełny skład Komisji zob.: ibidem, s. 146. 
projektu własnego lecz jako materiały do dalszej pracy. Popierający Zasady... Władysław Banaczyk (wiceprzewodniczący Rady Narodowej i członek KSU ze Stronnictwa Ludowego) zaproponował, by dokument przekazać do Komisji Prawno-Politycznej. Temu wnioskowi zdecydowanie zaprotestował Adam Ciołkosz z Polskiej Partii Socjalistycznej. Projekt nazwał „skandalem” i „wyrokiem śmierci na Polskę"3. Z kolei Adam Pragier, także z PPS, zauważył, że dokument nie jest ani wnioskiem rządu, ani Rady Narodowej, a jest prywatną prośbą premiera, jest więc pozakonstytucyjnym działaniem i brak mu podstaw formalnych do dalszego procedowania ${ }^{4}$. Wobec tych przeciwności Mikołajczyk wycofał projekt. Na wniosek Grabskiego Komisja Spraw Ustrojowych została rozwiązana uchwałą Rady Ministrów z dnia 15 grudnia 1942 roku, ale - jak zauważył Eugeniusz Duraczyński - nic nie wskazuje, by po marcowym posiedzeniu Rady Narodowej kontynuowała obrady.

Stanowisko liderów PPS-u, przyjęte prawdopodobnie na posiedzeniu Rady Narodowej, przyczyniło się do tego, że grono to, poszerzone o działaczy Stronnictwa Ludowego i trzech innych radnych, przygotowało na posiedzenie Rady własny wniosek w sprawie opracowania projektu ustroju państwa polskiego 5 . Dokument nosił datę 9 listopada 1942 roku. Za frakcję PPS podpisali go: Jan Szczyrek, Józef Beloński, Alojzy Adamczyk, Bogusław Kożusznik, Adam Pragier i Adam Ciołkosz. Za Stronnictwo Ludowe wniosek z projektem podpisali: Władysław Zaremba, Jan Jaworski i pochodzący z Grudziądza Witold Kulerski - syn Wiktora Kulerskiego. Wśród innych radnych, których podpisy widnieją pod dokumentem, znaleźli się przedstawiciele żydowskiego ruchu socjalistycznego „Bund” Szmul Zygielbojm i Mieczysław Szerer oraz bezpartyjny Arka Bożek ${ }^{6}$.

Autorzy wniosku opowiedzieli się za ustrojem republikańsko-demokratycznym zapewniającym państwu trwałość, sprawność i siłę rządów, a obywatelom możliwość wywierania wpływu na kształtowanie najwyższych władz w państwie i ich politykę, a także przez działalność pochodzącego z wyborów demokratycznych parlamentu, któremu zostanie przywrócona godność. Ustrój

3 E. Duraczyński, Rząd polski na uchodźstwie 1939-1945. Organizacja. Personalia. Polity$k a$, Warszawa 1993, s. 156.

${ }^{4}$ Ibidem, s. 156-157.

5 Instytut Polski i Muzeum Sikorskiego w Londynie (dalej: IPMS), Wniosek Stronnictwa Ludowego i Polskiej Partii Socjalistycznej (PPS) oraz innych niżej podpisanych - w sprawie opracowania projektu ustroju Państwa Polskiego, A. 5/16 b, k. 242-246.

${ }^{6}$ Ibidem, k. 246. 
powojennej Polski miał też gwarantować istnienie rozbudowanego szeroko samorządu terytorialnego, który miałby przejąć szereg funkcji dotychczas spełnianych przez administrację rządową. Wnioskodawcy przewidywali również istnienie samorządu gospodarczego, instytucji społecznych i zakładów naukowych. Ruch zawodowy robotników i pracowników umysłowych, a także inne samodzielne ruchy zawodowe oraz organizacje gospodarcze i spółdzielcze miały zachować pełny samorząd.

Ustrój państwa miał zapewniać również swobodę kształtowania i wyrażania opinii oraz organizowania życia ideowo-politycznego, społecznego i kulturalnego, poszanowania prawa i zasad etyki chrześcijańskiej w życiu publicznym ${ }^{7}$. Wszyscy obywatele Rzeczypospolitej mieli mieć zagwarantowane możliwie równe warunki startu życiowego. Postulat ten miał być zrealizowany poprzez zapewnienie powszechnego i bezpłatnego nauczania, zabezpieczającego każdemu obywatelowi „minimum wykształcenia ogólnego” i otwierającego „dostęp do skarbów kultury”. Z kolei „wszyscy lojalni obywatele Rzeczypospolitej” bez względu na wyznanie i narodowość mieli mieć zagwarantowane równe prawa.

Państwo polskie miało za zadanie dążyć do gospodarczego i politycznego związania się z innymi państwami Europy Środkowo-Wschodniej, a zwłaszcza z Czechosłowacją. Po wojnie miało wejść w związek wolnych narodów w Europie, dążąc do jego ścisłej współpracy, zapewniając jemu autorytet i siłę. Miało też przeciwdziałać próbom „[...] wewnętrznej dywersji, wybujałego nacjonalizmu oraz innych prądów antydemokratycznych, jak i zabezpieczyć związek ludów i jego członków przed niebezpieczeństwem inwazji zewnętrznej" . Celem przebudowy ustroju społecznego w zakresie społeczno-gospodarczym miał być sprawiedliwy podział dochodu. Ideał sprawiedliwości społecznej miał być zapewniony przez uspołecznienie „pewnych działów życia gospodarczego", a w dziedzinach nieuspołecznionych zmniejszenie różnic w rozmiarach posiadania i dochodu. Podstawą partycypacji w dochodzie miałaby być praca, gwarantująca każdemu obywatelowi „przyzwoity poziom życia”.

System miał być tak ukształtowany, by znosił jakikolwiek wyzysk człowieka. Projektowany ustrój miał się oprzeć na „wolnym, samodzielnym i uspołecznionym człowieku" ${ }^{10}$. Podstawą uspołecznienia miało być społeczeństwo

\footnotetext{
7 Ibidem, k. 242.

8 Ibidem.

9 Ibidem.

${ }^{10}$ Ibidem, k. 243.
} 
zorganizowane w spółdzielnie produkcyjne, rolnicze, spożywców, popierana byłaby produkcja samorządowa zwłaszcza w zakresie dóbr użyteczności publicznej. Upaństwowione miały być działy związane $\mathrm{z}$ obronnością państwa lub kluczowe dla gospodarki społecznej (kolej, poczta, komunikacja, przemysł wojenny, przemysły surowcowe, hutnictwo, źródła produkcji siły, kopalnie i bogactwa naturalne). Powszechną elektryfikację wsi i najmniejszych osiedli miało zagwarantować upaństwowienie siły elektrycznej. Samorząd miał sprawować nadzór nad drobnymi przedsiębiorstwami prywatnymi. Projekt zakładał, że rzemiosło pozostanie w rękach prywatnych. Wywłaszczeniu miały podlegać wielkie obszary ziemskie, a podstawą ustroju rolnego miał być samodzielny warsztat rolny, „[...] stanowiący własność osiadłego na nim rolnika i obrabiany rękami rodziny" ${ }^{\prime 1}$.

Zakładano, że na części terenów wywłaszczonych powstaną samorządowe lub państwowe wzorowe gospodarstwa rolne, stacje doświadczalne i gospodarstwa nasienne. Będzie obowiązywał zakaz spekulacji ziemią. Organizacja wymiany oprze się na spółdzielczości. W mieście i na wsi rozbudowana zostanie sieć instytucji ubezpieczeń społecznych i gospodarczych. Przebudowa ustroju społecznego miałaby usunąć czynniki ekonomiczne w antagonizmach narodowościowych. W sprawie żydowskiej postulowano zniesienie koncentracji handlu w rękach Żydów ${ }^{12}$. Gospodarka miała być planowa.

Co ważne, autorzy wniosku przewidywali, że ludność niemiecka, osadzana na ziemiach polskich w związku z planami germanizacyjnymi od pierwszego rozbioru, będzie przesiedlona do Niemiec. Przesiedleniu będą podlegali także ci, którzy podpisali listę Volksdeutsche. Na terytorium Polski będą mogli pozostać jedynie obywatele pochodzenia niemieckiego, których czyny i zachowanie w ostatniej wojnie i okupacji dowiodły przywiązania i wierności wobec państwa polskiego.

Rząd i Rada Narodowa miały przygotować dekrety dotyczące ${ }^{13}$ : reformy rolnej; wywłaszczenia i przekazania państwu, samorządowi i spółdzielczości przedsiębiorstw przemysłowych; reformy systemu podatkowego; unieważnienia aktów wydanych przez okupantów; odpowiedzialności karnej obywateli, którzy zdradzili Rzeczypospolitą; utworzenia trybunału, przed którym odpowiedzialność za nadużycia i szkody wyrządzone państwu, społeczeństwu

\footnotetext{
11 Ibidem.

12 Ibidem, k. 244.

13 Ibidem, k. 245.
} 
i obywatelom poniosą „dygnitarze cywilni i wojskowi reżimu sanacyjnego”; wyborów do sejmu i senatu z zachowaniem demokratycznego prawa wyborczego.

\section{Wnios e k}

\section{Stronnictwa Ludowego i Polskiej Partii Socjalistycznej (PPS) oraz innych niżej podpisanych - w sprawie opracowania projektu ustroju Państwa Polskiego ${ }^{14}$}

Podpisani wnoszą:

Rada Narodowa stoi na stanowisku, iż Rząd R.P. winien opracować projekt ustroju Państwa Polskiego oraz poleca własnym Komisjom Rady Narodowej opracowanie tez ustrojowych Państwa. Wszelkie prace w tym kierunku winny być oparte na następujących zasadach:

\section{W zakresie politycznym}

Ustrój państwa republikańsko-demokratyczny, zapewniający

a) państw u niezbędną trwałość, sprawność i siłę rządów, ob ywa te lo m możność wywierania wpływu tak na kształtowanie się najwyższych władz w państwie, jak i na ich politykę oraz działalność przez przywrócony do swej godności z demokratycznych wyborów pochodzący parlament oraz prawo plebiscytu i inicjatywy publicznej.

b) Szeroko rozbudowany sam orząd terytorialny, który przejmie szereg funkcji, spełnianych dotychczas przez administrację rządową, obok samorządu terytorialnego będzie mógł swobodnie rozwijać się samorząd gospodarczy, instytucji społecznych i zakładów naukowych. Ruch zawodowy robotników i pracowników umysłowych oraz inne samodzielne ruchy zawodowe, jak również organizacje gospodarcze i spółdzielcze zachowują pełny samorząd i otrzymują jednocześnie określone zadania w systemie Rzeczypospolitej.

${ }^{14} \mathrm{~W}$ tekście uwspółcześniono ortografię i interpunkcję. Podkreślenia pochodzą z oryginalnego tekstu. 
c) Sw ob od ę w kształceniu się i wyrażania opinii oraz w zorganizowaniu życia ideowo-politycznego, społecznego i kulturalnego na płaszczyźnie demokracji i niepodległości, jak i pełnego poszanowania prawa oraz zasad etyki chrześcijańskiej w życiu publicznym.

Ws zy s cy obywatele Rzeczypospolitej otrzymują możliwie równe warunki startu życiowego przez rzeczywiście powszechne i bezpłatne nauczanie, zabezpieczając każdemu obywatelowi niezbędne minimum wykształcenia ogólnego i otwierające dostęp do skarbów kultury.

Wszyscy lojalni obywatele Rzeczypospolitej bez różnicy wyznania i narodowości otrzymują równe prawa.

Ustrój demokratyczny będzie w Polsce należycie zabezpieczony przed wszelkimi wrogimi dążeniami.

Rzeczpospolita dążyć będzie do jak najściślejszego gospodarczego i politycznego związania się z innymi państwami Europy Środkowo-Wschodniej, zwłaszcza zaś z bratnia Republiką Czechosłowacką oraz wejdzie w skład związku wolnych ludów w Europie, reprezentując w nim dążenie do jak największej jego spoistości, autorytetu i siły, zarówno zdolnej unicestwić wszelkie próby wewnętrznej dywersji, wybujałego nacjonalizmu oraz innych prądów antydemokratycznych, jak i zabezpieczyć związek ludów i jego członków przed niebezpieczeństwem inwazji zewnętrznej.

W zakresie społeczno-gospodarczym celem przebudowy ustroju społecznego jest:

Sprawiedliwy podział dochodu społecznego. Przebudowa ta winna być dokonana w sposób, który nie tylko nie obniży wydajności produkcji, ale ją usprawni i podniesie w sposób zgodny z zasadami racjonalnej gospodarki; tylko na tej drodze będzie można osiągnąć powszechne podniesienie stopy życiowej mas pracujących w mieście i na wsi.

Realizowanie ideałów sprawiedliwości społecznej winno być uskutecznione drogą uspołecznienia pewnych działów życia gospodarczego, w dziedzinach zaś nieuspołecznionych - zmniejszenie do możliwych granic rozpiętości w posiadaniu i dochodzie.

Tytułem do uczestniczenia w dochodzie społecznym będzie p r a c a , która winna zapewnić każdemu obywatelowi przyzwoity poziom życia. Wszelkie możliwości wyzysku człowieka powinny być usunięte. 
Przebudowa ustroju społeczno-gospodarczego oraz polityka gospodarcza państwa muszą wychodzić z założenia ścisłej solida rności interesów wszystkich warstw pracujących i winna zmierzać do wprowadzenia i utrzymania równowagi w podziale dochodu społecznego między poszczególne grupy zawodowe świata pracy.

Budowa naszego ustroju oprze się przede wszystkim na wolny m, s amodzielnym i uspołecznionym człowieku.

Oparcie nowego porządku społecznego na szerokich masach będzie wyrazem istotnej demokratyzacji życia społecznego i gospodarczego i rozstrzygnie o jego dynamice rozwojowej. Podstawową formą uspołecznienia będzie przejęcie poszczególnych funkcji życia gospodarczego przez zorganizowane społeczeńs two (spółdzielnie, samorząd itp.). Spółdzielczość więc produkcyjna, rolnicza i spożywców, jako też produkcja samorządowa, zwłaszcza w zakresie produkowania dóbr użyteczności publicznej, znajdzie w nowym ustroju szerokie zastosowanie i należyte poparcie.

Up a ń s tw ow i e n i e będzie stosowane przede wszystkim do tych działów życia gospodarczego, które mają związek z obronnością państwa lub mają charakter kluczowy dla całości gospodarki społecznej (kolej, poczta, komunikacja, przemysł wojenny, przemysły surowcowe, hutniczy, źródła produkcji siły, skarby kopalniane i bogactwa naturalne itp.). Upaństwowienie produkcji siły elektrycznej umożliwi powszechną elektryfikację wsi i najmniejszych osiedli.

D robne przedsiębiorstwa prywatne zostaną objęte kontrolą społeczną przez samorządowe związki danej gałęzi produkcji i reprezentantów producentów i spożywców.

R z e mi o sło jako drobna wytwórczość przemysłowa pozostanie w zasadzie w prywatnym władaniu. Poszczególne działy rzemiosł winny stworzyć nadbudowę w formie spółdzielczej dla rozwiązywania wspólnych zagadnień, jak zakup surowca, zbyt wyrobów, wspólne korzystanie z urządzeń technicznych, organizacja kredytu itp. Na zasadach spółdzielczych winna się też oprzeć wytwórczość chałupnicza i przemysłu ludowego.

Wszelkie pozostałe jeszcze wielkie obszary ziemskie zostaną wywłaszczone. Podstawą ustroju rolnego będzie s a modzielny wa rs zta t rolny, stanowiący własność osiadłego na nim rolnika i obrabiany rękami rodziny. Na części terenów wywłaszczonych winny zostać utworzone samorządowe lub państwowe wzorowe gospodarstwa rolne, stacje doświadczalne, gospodarstwa nasienne itp. 
Wszelka s p e ku la c ja ziemią musi być uniemożliwiona.

Techniczne, ekonomiczne i organizacyjne braki drobnej gospodarki rolnej usunięte będą przez szeroko rozbudowaną spółdzielczość i równie szeroko rozbudowane szkolnictwo.

Organizacja w y m i a n y oprze się w przyszłym ustroju przede wszystkim na spółdzielczości. Aparat bankowo-kredytowy przejdzie w całości w ręce organizacji społecznej, samorządu terytorialnego i państwa. Polityka walutowa i gospodarczo-finansowa państwa zostanie dostosowana do ogólnych potrzeb gospodarstwa społecznego.

Sieć instytucji ubezpieczeń społecznych i gospodarczych na zasadzie wzajemności zostanie szeroko rozbudowana w mieście i na wsi.

Przebudowa ustroju społecznego usunie gospodarcze podstawy antagonizmów narodowościowych, a w szczególności w zakresie sprawy żydowskiej zniesie nienaturalne i jednostronne skupienie Żydów w handlu, jak również całkowicie usunie niektóre przerosty gospodarcze.

\section{Rozwój życia gospodarczego}

Oprze się na systemie gospodarki p la n ow ej. Plan gospodarczy będzie polegał na wytyczeniu kierunku i zasad rozwoju życia gospodarczego oraz na stwarzaniu ram działalności dla wszystkich elementów biorących udział w produkcji, wymianie towarowej i pieniężnej.

\section{Organizacja życia gospodarczego}

Oprze się na samorządzie gospodarczym, reprezentującym poszczególne gałęzie życia gospodarczego, a skupiającym w swych szeregach wszystkie zainteresowane elementy społeczne, a więc: robotników, pracowników umysłowych oraz właścicieli zakładów przemysłowych, handlowych i rolnych (państwowych, uspołecznionych i prywatnych).

Poszczególne działy produkcji przemysłowej i rzemieślniczej, tworzące odrębne związki według gałęzi przemysłu, znajdą swoją koordynację w postaci wojewódzkiej izby przemysłowej, współdziałającej z wojewódzką izbą rolniczą.

\section{Nadbudową poszczególnych działów samorządu gospodarczego będzie:}

Naczelna Izba Gospodarcza, której najważniejszym uprawnieniem będzie: reprezentacja wszystkich gałęzi życia gospodarczego w stosunku do administracji państwowej, planowanie i koordynacja życia gospodarczego. 
Nad całością życia gospodarczego i nad działalnością gospodarczej organizacji przemysłowej i związków poszczególnych gałęzi produkcji roztacza kontrolę i opiekę państwo. Ma ono w szczególności na uwadze, by wyniki całości gospodarki dostarczyły odpowiednich środków obrony i ugruntowały znaczenie Polski między innymi narodami.

\section{Zarządzenia przejściowe}

Ludność niemiecka osadzona na ziemiach polskich w intencjach germanizacyjnych - w szczególności poczynając od pierwszego rozbioru - zostanie przesiedlona do Niemiec. To samo tyczyć będzie tych wszystkich, którzy ogłosili się tzw. Volksdeutsche. Pozostać w granicach Polski będą mogli tylko ci obywatele pochodzenia niemieckiego, którzy czynami swymi, a w szczególności zachowaniem się swoim w czasie obecnej wojny i okupacji stwierdzili swoje przywiązanie i wierność dla państwa polskiego.

\section{Pierwsze dekrety w przywróconej wolności Polsce}

Rząd i Rada Narodowa przygotują projekty dekretów, które przeprowadzą:

a) reformę rolną przez wywłaszczenie większych obszarów i stworzenie $z$ nich zasobu ziemi do parcelacji, oddając natychmiast obszary wywłaszczone pieczy gminnych i powiatowych komitetów reformy rolnej, celem oddania ich następnie w ręce rolników;

b) wywłaszczenie i przekazanie państwu, samorządowi i spółdzielczości dojrzałych do uspołecznienia prze[d]siębiorstw przemysłowych, stwarzając dla nich jednocześnie uspołecznione warstwy społeczne;

c) reformę systemu podatkowego zmierzającego do sprawiedliwego rozłożenia ciężarów podatkowych na wszystkie warstwy społeczne;

d) unieważnienie wszystkich aktów wydanych przez okupantów w zakresie mienia i dobrobytu obywateli Rzeczypospolitej, przekazują to mienie dla zabezpieczenia powołanym w tym celu instytucjom społecznym do czasu objęcia ich przez uprawnionych właścicieli;

e) odpowiedzialność karna wszystkich obywateli, którzy zdradzili Rzeczypospolitą przez wysługiwanie się okupantom;

f) utworzenie specjalnego trybunału, przed którym staną dygnitarze cywilni i wojskowi reżimu sanacyjnego, odpowiedzialni za jego nadużycia i szkody wyrządzone państwu, społeczeństwu i obywatelom; 
g) wybory do Sejmu i Senatu na zasadach demokratycznego prawa wyborczego.

\section{UZASADNIENIE}

Zdajemy sobie sprawę z tego, że o przyszłym ustroju Polski zadecydują ostatecznie wszyscy obywatele państwa polskiego, że dopiero po zrzuceniu potwornej okupacji Polska uzyska pełnię swego głosu.

Nie znaczy to jednak, aby Polska dlatego, że jest okupowana, była teraz pozbawiona głosu w sprawach urządzenia się wewnętrznego i w sprawie swego stosunku do wszystkich wolnych narodów. Tym więcej, że nie jest nieznanym głos okupowanej Polski.

Polska trwa niewzruszenie $\mathrm{w}$ wojnie $\mathrm{z}$ imperializmem niemieckim, w wojnie z „Nowym Ładem”, jaki chcą narzucić światu państwa „Osi”. Polska złączyła nierozerwalnie swą przyszłość z wolnymi narodami. Ta postawa narodu polskiego nie jest koniunkturalną. Zawsze wolność i niepodległość Polski były związane ze sztandarami wolności i demokracji. Wraz z wolnymi narodami Polska chce wygrać nie tylko wojnę, ale także i pokój. Pokój nie tylko w stosunku do barbarzyńskich Niemców, ale też pokój w rodzinie zjednoczonych wolnych narodów.

Kraje okupowane, walczące wraz z całym światem o wolność, przeżywają w tej wojnie tak głęboki wstrząs, że wszędzie pracuje myśl ludzka nad usunięciem w s z y t k i ch przyczyn obecnego straszliwego konfliktu, co jest równoznaczne z głęboko sięgającą przebudową ustroju społecznego i gospodarczego. Nad tą przebudową pracują umysły wszystkich narodów. Nie brakuje, bo nie może brakować w tej pracy twórczej i narodu polskiego.

Legitymacją do wniesienia tych zasad ustrojowych na warsztat ustawodawczej pracy Rady Narodowej jest fakt, że opracowane zostały one w Kraju, pod okupacją. Okoliczność ta świadczy, że Polacy stojący twarzą w twarz z faszyzmem, spotykający się na każdym kroku z dobrodziejstwami „nowego ładu” chcą mieć Polskę demokratyczną w najpełniejszym tego słowa znaczeniu. Tam w Kraju Polacy najlepiej i najgłębiej zrozumieli, co znaczy stracić wolność i najlepiej wiedzą, jakimi środkami i jakimi drogami trzeba i można przed jej utratą się zabezpieczyć.

Jesteśmy w całości, wszyscy, całą duszą i sercem solidarni z ideałami, które przyświecają rodakom w Kraju. Jesteśmy też głęboko przekonani, że ten projekt ustroju Polski odpowiada woli i pragnieniu całego narodu i wszystkich Polaków rozrzuconych dziś po całej niemal kuli ziemskiej. Przedkładamy go 
Radzie Narodowej z całym poczuciem odpowiedzialności, że przedstawia on wolę całej Polski Walczącej.

Londyn, dnia 9.XI.1942

Za fr. P.P.S.

/-/ J. Szczyrek

/-/ J. Beloński

/-/ A. Adamczyk

/-/ Dr Kożusznik

/-/ A. Pragier

/-/ A. Ciołkosz
Za Str. Lud.:

/-/ Zaręba Wt.

/-/ W. Kulerski

/-/ Jaworski Jan
Inni

/-/ S. Zygielbojm

/-/ Miecz. Szerer

/-/ Arka Bożek 